\title{
An integrated approach to cost comparisons of different tailings management options
}

\author{
A Carneiro The University of Western Australia, Australia \\ AB Fourie The University of Western Australia, Australia
}

\begin{abstract}
There are growing expectations of mining companies to operate in a more sustainable manner, with a strong business case for improving waste management and reducing environmental impacts. As the stewardship of tailings come under increasing scrutiny, decision-makers are urged to adopt a robust approach to the selection of a tailings management strategy that encompasses design for closure, and leading practices to lower the risk of catastrophic dam failures, optimise the use of resources, and mitigate environmental impacts on climate change. An integrated analysis, considering economic, environmental, social, and risk aspects of the operation can therefore provide decision-makers with balanced information to ensure the right projects proceed with an optimal business case so that the most cost-effective solution, that does not externalise costs, can be selected. However, literature review revealed that fundamental shortcomings exist within traditional evaluation approaches used for economic comparisons. This paper reports on life cycle cost analyses conducted for comparing various tailings management options under different scenarios. A conceptual case study for the disposal of gold tailings in Western Australia as a slurry, as thickened, or as filtered tailings, was considered. This was done for examining the extent to which potentially hidden costs impact on the total cost of a project. It is suggested that the proposed approach will lead to selection of a tailings management alternative that ensures sound economic, environmental, and social performance is achieved.
\end{abstract}

Keywords: tailings management, cost comparison, mine closure, life cycle assessment, sustainable mining

\section{$1 \quad$ Introduction}

There are growing expectations of mining companies to operate in a more sustainable manner, with a strong business case for improving waste management and reducing environmental impacts. As the stewardship of tailings come under increasing scrutiny, selecting an alternative strategy for tailings management that meets increasingly stringent regulations with regards to land rehabilitation, the use of resources, and climate change concerns involves great challenges. Decision-makers have been given the task of managing and delivering projects which are not only required to be economically viable, but also need to be environmentally and socially sustainable. A robust approach to the selection of a tailings management option that encompasses design for closure, and leading practices to lower the risk of catastrophic dam failures, optimise the use of resources such as water, energy, and land, and mitigate environmental impacts is thus urgently required.

One significant example of the compelling business case for applying sustainable development principles in tailings management is the International Council on Mining and Metals' (ICMM) increasing emphasis on the governance of tailings storage facilities (TSF). The ICMM recently published a document entitled Position statement on preventing catastrophic failure of tailings storage facilities (ICMM 2016). It is intended to serve as a framework for enhancing the industry's focus on key elements of management and governance necessary to maintain the integrity of TSFs and minimise the risk of tailings disasters. Moreover, the ICMM has also reviewed its Sustainable Development Framework (ICMM 2015), which needs to be implemented by all member companies as a condition of membership. It contains the ICMM 10 Principles, of which Principle 2 (Integrate sustainable development in corporate strategy and decision-making processes) and Principle 6 (Pursue continual improvement in environmental performance issues, such as water stewardship, 
energy use and climate change) deserve particular attention in the context of conducting economic evaluations for the selection of a tailings management option.

An integrated analysis, considering economic, environmental, social, and risk aspects of the operation can therefore provide decision-makers with balanced information to ensure the right projects proceed with an optimal business case so that the most cost-effective solution that does not externalise costs can be selected. However, an analysis of the current approaches adopted for selecting a tailings management strategy evident from a review of the public domain literature is that the methodologies selected for comparing costs of alternative options are limited (Carneiro \& Fourie 2017, 2018; Johnson et al. 2013; Moreno et al. 2018). Generally, comparative studies account mainly for capital and operating costs only, and only for certain items that are specific to the project. As a result, it is possible that at the time a tailings management option was selected, the true closure costs were underestimated, and less tangible expenses were overlooked. Once internalised, otherwise hidden costs can significantly affect the financial viability of a project and possibly impede its development.

Compounding the scale of the problems associated with a narrow set of parameters used for cost estimations is the persistent use of traditional discounting procedures for cost calculations. The most common methodology adopted for determining the most feasible solution for tailings management relies on selecting the option that minimises its net present cost (NPC), i.e. the discounted value of the stream of annual costs at a chosen discount rate. When applied to long-life projects, future costs (e.g. the costs of TSF closure) are effectively reduced to a small present value, which can lead to the selection of TSF designs that can have detrimental long-term closure cost implications. This approach is particularly unsuitable for evaluating TSF projects, which can incur potentially increased rehabilitation costs at the time of closure compared to the costs envisaged during the project feasibility evaluation phase (Cummings 2014; Department of Foreign Affairs and Trade 2016; Espinoza \& Morris 2017; McPhail 2006; Robins 2004).

Given the above, this paper reports on life cycle cost analyses conducted for comparing various tailings management options under different scenarios. A conceptual case study entailing a gold operation in Western Australia (WA) was considered. Based on selected tailings physical characteristics and operating parameters, suitable project designs were developed for managing the tailings as a slurry, as thickened, or as filtered tailings. The life cycle cost of each project option was calculated under six different scenarios:

1. Base case scenario in which a traditional discounting approach was adopted for assessing the options in terms of the total cost of the project.

2. Closure scenario in which higher rehabilitation costs compared to the costs estimated in the base case scenario, and a lower discount rate for discounting them were considered.

3. Water scenario in which a cost was assumed for the supply of make-up water.

4. Land scenario in which a cost was assumed for land use.

5. Carbon tax scenario in which a cost was assigned to the emissions of greenhouse gases (GHG).

6. Potential total life cycle costs scenario in which the sum of all the costs accounted for in the other scenarios were considered in the evaluation.

This was done for examining the extent to which potentially hidden costs impact the total cost of a project. It is suggested that the proposed approach will lead to selection of a tailings management alternative that ensures sound economic, environmental, and social performance is achieved.

\section{$2 \quad$ Material and methods}

\subsection{The conceptual case study}

This case study relates to the management of a hypothetical, yet typical non-acid generating gold tailings stream to be disposed of in the Goldfields region of WA. The tailings (particle size distribution of $75-80 \%$ less 
than $75 \mu \mathrm{m}$, and specific gravity of the solids of 2.79) are assumed to be originated from the beneficiation of gold ore in a mineral processing plant involving crushing, grinding, flotation, carbon-in-leach, and dewatering circuits. Tailings will be transported to a disposal area set $1 \mathrm{~km}$ away from the plant in a topographically flat terrain. Selected operating parameters are based on an annual production rate of $2 \mathrm{Mt}$ of tailings solids, resulting in a total of $30 \mathrm{Mt}$ to be disposed of over the assumed 15-year operating life-of-mine (LOM).

Four project designs (Options $A, B, C$, and D) entailing various tailings management strategies were developed for this study, including the management of the tailings as a slurry, as thickened, and as filtered tailings. Different tailings management strategies involve producing different types of tailings along with associated different dewatering equipment, tailings transport systems, disposal methods, TSF layouts, approaches to water management, and strategies for the rehabilitation of disturbed areas. The main design considerations selected for each tailings project option are summarised in Table 1.

Table 1 Main selected design considerations for each tailings management option

\begin{tabular}{|c|c|c|c|}
\hline \multirow{2}{*}{ Item } & \multicolumn{3}{|c|}{ Tailings management option } \\
\hline & Options A and B & Option C & Option D \\
\hline $\begin{array}{l}\text { Solids content of } \\
\text { discharged tailings }\end{array}$ & $55 \%$ & $65 \%$ & $80 \%$ \\
\hline $\begin{array}{l}\text { Dry density of } \\
\text { deposited tailings }\end{array}$ & $1.4 \mathrm{t} / \mathrm{m}^{3}$ & $1.5 \mathrm{t} / \mathrm{m}^{3}$ & $1.8 \mathrm{t} / \mathrm{m}^{3}$ \\
\hline Dewatering unit type & High-rate thickener & $\begin{array}{l}\text { High-compression } \\
\text { thickener }\end{array}$ & Pressure filter \\
\hline $\begin{array}{l}\text { Tailings transport } \\
\text { system }\end{array}$ & $\begin{array}{l}\text { Five centrifugal plus } \\
\text { five standby pumps and } \\
\text { pipeline }\end{array}$ & $\begin{array}{l}\text { One positive displacement } \\
\text { pump plus two charge } \\
\text { pumps and pipeline }\end{array}$ & Trucks \\
\hline $\begin{array}{l}\text { Tailings disposal } \\
\text { method }\end{array}$ & $\begin{array}{l}\text { Spigotting from a slurry } \\
\text { ring }\end{array}$ & $\begin{array}{l}\text { Central thickened } \\
\text { discharge (CTD) }\end{array}$ & Placement by dozers \\
\hline TSF layout & $\begin{array}{l}\text { Paddock-type dam with } \\
\text { square shape }-1 \mathrm{~V}: 3 \mathrm{H} \\
\text { side slopes }\end{array}$ & $\begin{array}{l}\text { Conical deposit with an } \\
\text { average } 2 \% \text { beach slope } \\
\text { and } 1 \mathrm{~km} \text { radius }\end{array}$ & Dry-stack (1V:4H) \\
\hline $\begin{array}{l}\text { TSF embankment } \\
\text { construction method }\end{array}$ & $\begin{array}{l}\text { Upstream (Option A) } \\
\text { and downstream } \\
\text { (Option B) }\end{array}$ & $\begin{array}{l}\text { Perimeter environmental } \\
\text { embankment ( } 2 \mathrm{~m} \text { high } \\
\text { berm) }\end{array}$ & - \\
\hline $\begin{array}{l}\text { Flow of water } \\
\text { discharged with } \\
\text { tailings }\end{array}$ & $189 \mathrm{~m}^{3} / \mathrm{hr}$ & $125 \mathrm{~m}^{3} / \mathrm{hr}$ & $58 \mathrm{~m}^{3} / \mathrm{hr}$ \\
\hline $\begin{array}{l}\text { Approach to water } \\
\text { management }\end{array}$ & $\begin{array}{l}\text { Underdrainage system } \\
\text { and decant pond }\end{array}$ & $\begin{array}{l}\text { Pond for the collection of } \\
\text { precipitation runoff }\end{array}$ & $\begin{array}{l}\text { Pond for the collection } \\
\text { of precipitation runoff }\end{array}$ \\
\hline Rehabilitation strategy & $\begin{array}{l}\text { Cap TSF with a layer of } \\
\text { hard rock, place topsoil } \\
\text { and revegetate all } \\
\text { disturbed areas }\end{array}$ & $\begin{array}{l}\text { Fill pond with hard rock, } \\
\text { place topsoil and } \\
\text { revegetate TSF and all } \\
\text { disturbed areas }\end{array}$ & $\begin{array}{l}\text { Progressive } \\
\text { rehabilitation of the } \\
\text { TSF, and fill pond with } \\
\text { hard rock at the end of } \\
\text { the LOM }\end{array}$ \\
\hline TSF footprint area & $\begin{array}{l}94 \text { ha (Option A), } 107 \text { ha } \\
\text { (Option B) }\end{array}$ & 324 ha & 49 ha \\
\hline
\end{tabular}


Option A entails the management of the tailings as a slurry at a solids content of $55 \%$ (where solids content is defined as the weight of solids as a percentage of the total weight of the pulp). Tailings will be deposited sub-aerially from discharge points evenly spaced along the perimeter embankment of a paddock-type facility. Major TSF infrastructure components include a starter embankment, an underdrainage system, and a decant structure. During the operating LOM, TSF capacity will be increased by raising the embankment using coarse-grained tailings harvested from the adjacent tailings beach, following the concepts of the upstream method of construction. Consolidation water from the tailings and collected precipitation runoff in the decant pond will be pumped to the plant, while make-up water will be sourced from a catchment point set $5 \mathrm{~km}$ away. As tailings deposition ceases, the TSF will be left drying for a period of three years before rehabilitation work can start. The rehabilitation involves hauling and placing a layer of hard rock on the top and side slopes of the TSF, and capping with topsoil and revegetating all disturbed areas. Then, three years were considered for regulatory approval of the rehabilitation strategy, and another 10 years for post-closure environmental monitoring were assumed for meeting closure criteria and completion of the project's lifespan. The assumption is thus that it will take 34 years from the start of the project to final relinquishment.

Similar to Option A, Option B also entails the management of the tailings as a slurry at a solids content of $55 \%$, but it involves increasing TSF capacity by raising the embankment using the downstream method of construction. It was designed for the purpose of evaluating the impacts on the costs versus an improvement in the robustness of the TSF to lower the risk of failure.

Compared to Options $A$ and $B$, Option $C$ involves the management of the thickened tailings at a solids content of $65 \%$, and includes a smaller TSF perimeter embankment (in terms of height and volume), a lined pond next to the TSF for surface water management, and a spine access way for the discharge of the tailings using the concepts of central thickened discharge (CTD) method.

Significantly differing from the other options, Option $D$ involves the management of filtered tailings at a solids content of $80 \%$. Filtered tailings will be produced in a filtration plant comprising plate-and-frame filter units, transported to a dry-stack-type TSF by trucks, and placed by dozers (only traffic compaction was considered for the storage of filtered tailings). Throughout the operating LOM, spare and wearing parts for the filtration plant (e.g. filter cloths) will be required, collected precipitation runoff within the dry-stack footprint will be pumped to the plant, and progressive rehabilitation will occur concurrent to tailings disposal. More details about the project designs involving this case study can be found in Carneiro and Fourie $(2017,2018)$.

\subsection{Life cycle cost calculation and scenarios definition}

For the purposes of this paper, life cycle cost calculations consisted of estimating the total cost of the project over its life time. Six scenarios were developed for assessing the project options in terms of their NPC, namely base case scenario, closure scenario, water scenario, land scenario, carbon tax scenario, and potential total life cycle costs scenario. Key elements that may represent a project constraint for the chosen site-specific conditions, and which are likely to perhaps become more expensive in the context of increasing pressure on mining companies to adopt more sustainable practices, were tested. This was done to examine the extent to which uncertainties and potential sources of variability surrounding mine closure, the use of natural resources (water and land), and environmental regulations with regards to climate change affect the total costs of tailings management.

Under all scenarios evaluated, the NPC of each project option was estimated using discounting methodologies, in which future costs were discounted to present dollar values calculated using discount rates. In the base case scenario, a flat discount rate was used for discounting the stream of future annual costs. In the closure scenario, future rehabilitation costs were considered to have tripled when compared to the costs envisaged in the base case scenario, and different discount rates were used for discounting the operating and closure costs. Comparable to the base case scenario, the water scenario differs because it considered a cost for the supply of make-up water, the land scenario considered a cost for land use, and the carbon tax scenario considered a cost for the amount of GHG scope 1 emitted (where scope 1 emissions are defined as the emissions released to the 
atmosphere as a direct result of an activity) (National Greenhouse and Energy Reporting 2018). Finally, the potential total life cycle costs scenario considered the sum of all the costs accounted for in the other scenarios.

The GHG emissions of each project option were quantified using the life cycle assessment (LCA) methodology described by the International Organization for Standardization (ISO) on environmental management (ISO 2006a, 2006b). SimaPro software version 8.5 (PRé Consultants 2019) was used for life cycle inventory and life cycle impact assessment modelling, and the International Panel on Climate Change (IPCC) global warming potential (GWP) 2013 impact assessment method was selected for the LCA study. Developed by the IPCC, the IPCC GWP 2013 method focuses on the environmental impacts on climate change caused by the three main GHG (carbon dioxide $\left(\mathrm{CO}_{2}\right)$, methane $\left(\mathrm{CH}_{4}\right)$, and nitrous oxide $\left(\mathrm{N}_{2} \mathrm{O}\right)$ ) emissions, recorded in $\mathrm{CO}_{2}$ equivalents $\left(\mathrm{CO}_{2}\right.$ eq) for comparison (PRé Consultants 2018).

\subsection{Cost parameters and assumptions}

The main cost items considered for estimating the NPC of each project option are presented in Table 2.

Table 2 Major cost items considered in the life cycle cost calculations

\begin{tabular}{|c|c|c|c|}
\hline $\begin{array}{l}\text { Major cost } \\
\text { items }\end{array}$ & $\begin{array}{l}\text { Tailings management option } \\
\text { Options A and B }\end{array}$ & Option C & Option D \\
\hline \multirow{9}{*}{ Capital costs } & Thickener & Thickener & \multirow{4}{*}{ Filtration plant } \\
\hline & Tailings pumps & Tailings pump & \\
\hline & Tailings pipeline & Tailings pipeline & \\
\hline & $\begin{array}{l}\text { Pipe for spigot dropper and } \\
\text { spigot offtakes }\end{array}$ & Spigot offtakes & \\
\hline & Site preparation & Site preparation & Site preparation \\
\hline & Starter embankment & Environmental embankment & - \\
\hline & $\begin{array}{l}\text { Underdrainage, decant } \\
\text { structure and pond }\end{array}$ & $\begin{array}{l}\text { Pond for water } \\
\text { management and runoff } \\
\text { trench }\end{array}$ & $\begin{array}{l}\text { Pond for water } \\
\text { management and runoff } \\
\text { trench }\end{array}$ \\
\hline & $\begin{array}{l}\text { Make-up and return water } \\
\text { pumps and pipeline }\end{array}$ & $\begin{array}{l}\text { Make-up and return water } \\
\text { pumps and pipeline }\end{array}$ & $\begin{array}{l}\text { Make-up and return water } \\
\text { pumps and pipeline }\end{array}$ \\
\hline & - & Spine access way & - \\
\hline \multirow{7}{*}{$\begin{array}{l}\text { Operating } \\
\text { costs }\end{array}$} & Dewatering energy & Dewatering energy & Dewatering energy \\
\hline & Flocculant & Flocculant & - \\
\hline & $\begin{array}{l}\text { Pumping energy for tailings } \\
\text { transport }\end{array}$ & $\begin{array}{l}\text { Pumping energy for tailings } \\
\text { transport }\end{array}$ & $\begin{array}{l}\text { Tailings transport by truck } \\
\text { and placement by dozer }\end{array}$ \\
\hline & Pump spares & Pump spares & $\begin{array}{l}\text { Filtration plant spares and } \\
\text { wearing parts }\end{array}$ \\
\hline & $\begin{array}{l}\text { Wall raising to increase TSF } \\
\text { capacity }\end{array}$ & $\begin{array}{l}\text { Spine access way raising to } \\
\text { increase TSF capacity }\end{array}$ & - \\
\hline & $\begin{array}{l}\text { Pumping energy of make-up } \\
\text { and return water }\end{array}$ & $\begin{array}{l}\text { Pumping energy of make-up } \\
\text { and return water }\end{array}$ & $\begin{array}{l}\text { Pumping energy of make-up } \\
\text { and return water }\end{array}$ \\
\hline & $\begin{array}{l}\text { Levy payable to the Mining } \\
\text { Rehabilitation Fund (MRF) }\end{array}$ & Levy payable to the MRF & Levy payable to the MRF \\
\hline \multirow{2}{*}{$\begin{array}{l}\text { Closure } \\
\text { costs }\end{array}$} & Rehabilitation & Rehabilitation & Rehabilitation \\
\hline & Post-closure monitoring & Post-closure monitoring & Post-closure monitoring \\
\hline
\end{tabular}


Three cost areas were considered for life cycle cost calculation; capital costs, operating costs, and closure costs. The capital costs consist of fixed, one-time expenditures to be incurred by the purchase and installation of equipment, and the construction of the infrastructure required prior to the commencement of operations. The operating costs consist of expenses associated with tailings dewatering, transport, and placement, TSF operation (wall raising and water pumping), and the annual levy payable to the Mining Rehabilitation Fund (MRF), which is required for mining operators in WA (Department of Mines, Industry Regulation and Safety 2013). The closure costs consist of earthworks expenses for the rehabilitation of disturbed areas, and on annual costs of post-closure monitoring until the end of the LOM.

The estimated NPCs in this study are inclusive of a relatively high level of detail if compared to other comparative studies found in the literature, but are not representative of all the costs to produce and store the tailings. It is important to note that some of unconsidered costs would ultimately affect the NPC of each project option, thus the costs presented in this study should be viewed with caution. For instance, despite different and significant volumes of construction materials being needed for each project, it was assumed that sufficient quantities would be available onsite. Therefore, the supply costs of construction materials were not accounted for in the cost estimates.

\section{$3 \quad$ Results and discussion}

\subsection{Life cycle costs estimated under the base case scenario}

Figure 1 shows the estimated life cycle costs of each project option, presented as cumulative costs over the LOM, obtained from the financial analysis performed under the base case scenario. A discount rate of $10 \%$ was used for discounting the stream of future annual expenses. Comparative NPCs indicate that the project option designed for the management of thickened tailings (Option C) results in the lowest cost, while the highest cost is for the filtered tailings solution (Option D). The estimated unit cost per tonne of tailings solids is AUD 0.90, AUD 1.86, AUD 0.85, and AUD 2.32 for the Options A, B, C, and D, respectively.

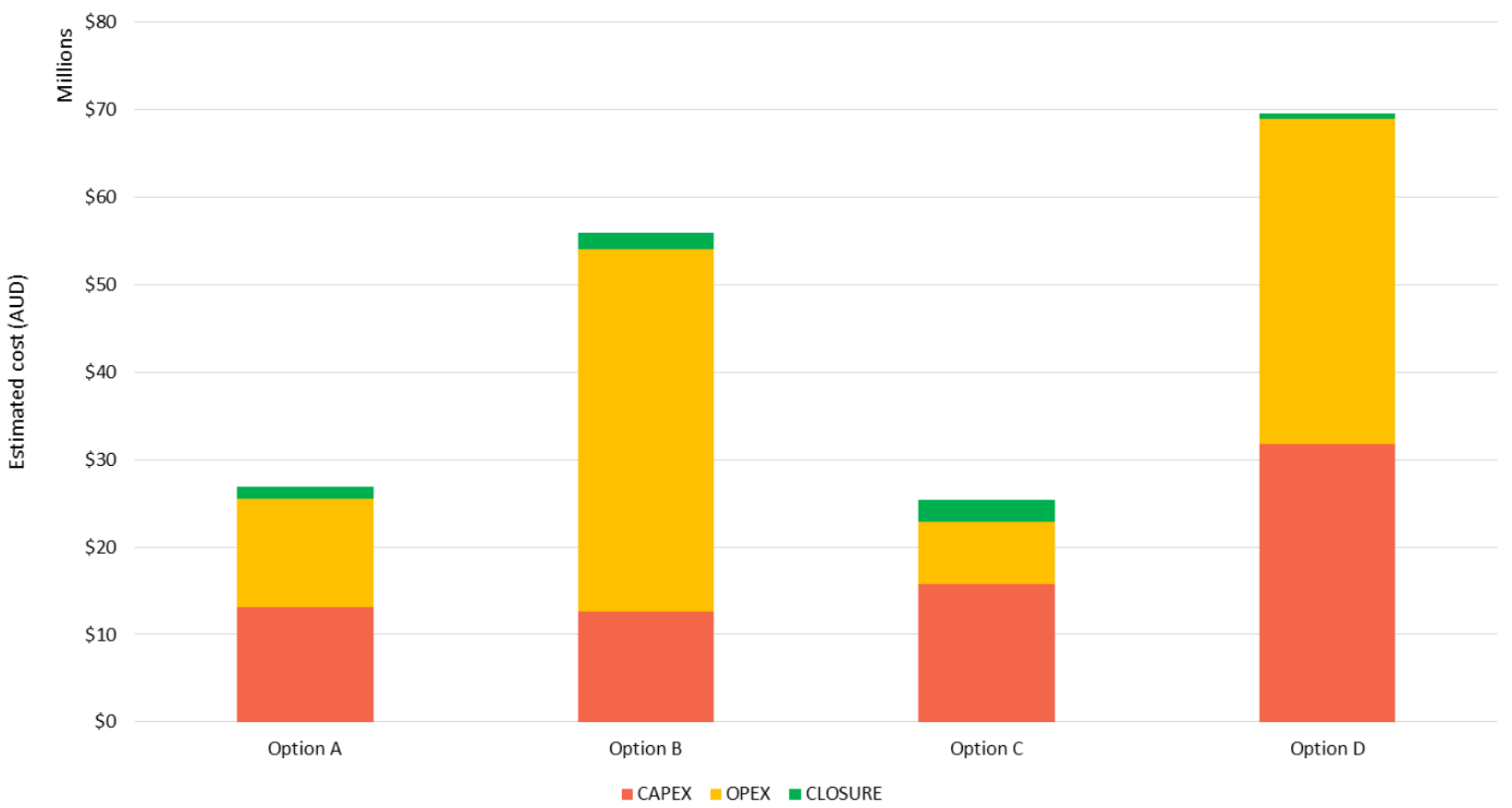

Figure 1 Comparative life cycle costs estimated under the base case scenario (including 10\% of annual discount rate)

Comparative results show that the highest capital costs are for the filtered tailings solution (Option D), the highest operating costs are for the slurry tailings alternative that uses downstream method for raising the TSF perimeter embankment (Option B), and the highest closure costs are for managing thickened tailings 
(Option C). The fact that there was no project option that had a cost advantage over the other options in all the assessed LOM phases highlights important aspects with regards to the relationship between the adopted strategy for tailings management and the elements driving the costs of disposal.

The distribution of annual costs throughout the LOM for each project option can be observed in Figure 2 . In the construction phase (from year 0 to year 2), comparative up-front capital required for the projects shows that the investment cost is lowest for Option B. Despite selected plant and ancillary equipment for Options A and B being the same, raising the TSF embankment of Option B downstream means that less site preparation and a lower volume starter embankment will be required at the beginning of the LOM. For Options A, B, and C, the key elements driving the capital costs (approximately 60\%) are associated with the earthworks required for site preparation and construction of the TSF and associated infrastructure. For Option D, capital costs are dominated $(94 \%)$ by the supply and installation of the filtration plant, which includes three filter hydraulic units, three slurry feed pumps, one cake pressing compressor, three dry air compressors, two manifold flush pumps, two cloth wash pumps, three filtrate pumps, three cake conveyors for cake discharge, and one slurry tank agitator.

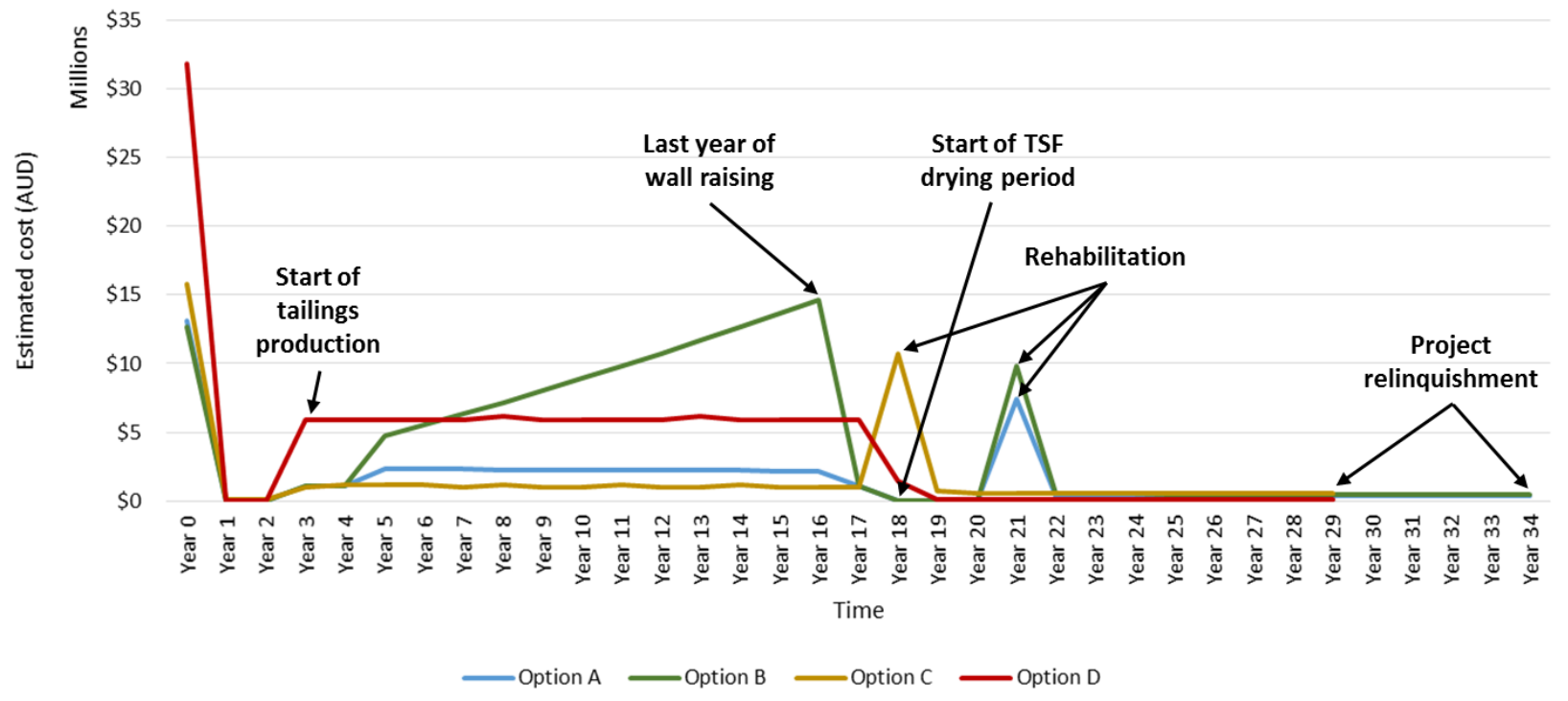

Figure 2 Distribution of expected annual costs estimated under the base case scenario

In the operating phase (from year 3 to year 17), Option $C$ has the cost advantage because its operating costs are $75 \%$ lower than the operating costs of Option $A$, and more than four-times lower than the operating costs of Options B and D. Option B has the highest estimated operating costs, with the earthwork costs of raising the TSF walls throughout the LOM being the major contributor (83\%). As the TSF gets higher, the volume of low permeability fill needed for raising the embankment using the downstream method of construction increases, resulting in an average growth of $2.6 \%$ in the operating costs from year to year, reaching the peak of almost AUD $15 \mathrm{M}$ needed for the last year that the embankment will be raised (year 16). The second highest operating costs are for Option $D$ due to the transport and placement of filtered tailings by earthmoving equipment, which represent $63 \%$ of the total operating costs expected for this option. Operating expenditures of the filtration plant, expressed by relatively high power consumption, and the requirement for spare and wearing parts in the filters and ancillary equipment also contributes to the high operating costs of Option D (35\%).

In the closure phase (from year 18 until the end of the LOM), Option D is the least expensive as it is the option that requires the smallest footprint for tailings management. The highest closure costs are for the Option $\mathrm{C}$, being almost five-times the closure costs of Option $\mathrm{D}$. The project designed for Option $\mathrm{C}$ will disturb an area of approximately 344 ha, compared to 97,110 , and 56 ha of area to be disturbed by the projects designed for Options A, B, and D, respectively. It is because the CTD method of disposing tailings results in a relatively low-elevation tailings deposit covering a very large footprint. High costs associated with hauling and placing 
large volumes of topsoil to cap the TSF, and hard rock to fill the pond for collecting precipitation runoff from the vast catchment area are then expected.

\subsection{Life cycle costs estimated under the other assessed scenarios}

Figure 3 shows a comparison of the estimated life cycle costs of the project options presented as cumulative costs over the LOM obtained from the financial analyses performed under all the assessed scenarios. The results show that there was no tailings management option that has an absolute cost advantage or disadvantage over the other options in all the evaluated scenarios. This is very important to note because it corroborates the knowledge that there is no 'one-size-fits-all tailings panacea'. Depending on project constraints due to site-specific conditions, varying elements will drive the costs of tailings management, and a preferred option under one case scenario may be the least preferred choice under different project settings.

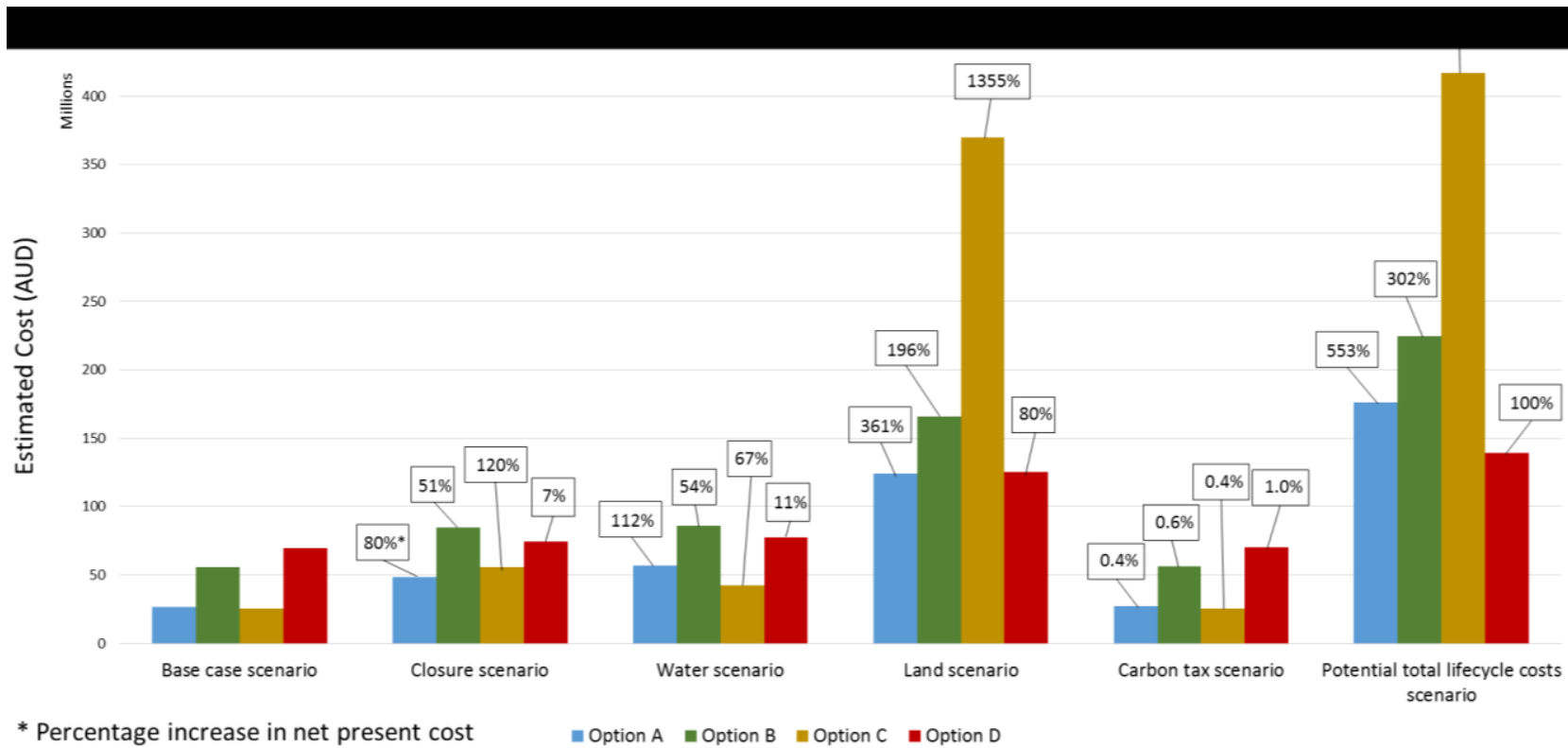

Figure 3 Comparative estimated life cycle costs resulting from the financial analyses of all assessed scenarios

\subsubsection{Closure scenario}

In the closure scenario, the NPC of each project option was estimated using a discount rate of $10 \%$ for discounting the annual operating costs and $2 \%$ for calculating the closure costs. Expected rehabilitation expenditures were also assumed to be three-times the costs estimated in the base case scenario. The objective of evaluating the project options under the closure scenario was to account for the uncertainties associated with mine closure planning and the future costs of rehabilitation. The concepts of the hurdle rate technique, which relies on using different discount rates for calculating present values according to the level of uncertainty around the value of expected costs presented in Gluch and Baumann (2004), were applied.

Comparative results reveal that the use of a lower discount rate for discounting increased rehabilitation costs changed the rank between the project options. The unit cost per tonne of tailings solids to be disposed of was estimated as AUD 1.61, AUD 2.82, AUD 1.86, and AUD 2.49 for the Options A, B, C, and D, respectively. Capital and operating costs are the same as in the base case scenario but increasing the influence of potentially higher closure costs on the total cost of the project (by the means of using a lower discount rate) significantly increased the costs of managing thickened tailings (Option $\mathrm{C}$ ). The life cycle cost of the project increased by about $80 \%, 51 \%$ and $120 \%$ for the Options A, B, and C, respectively, whereas the life cycle costs of Option D increased by only $7 \%$.

It is important to note that under the base case scenario, the cost of rehabilitating the area disturbed by the project at the time of mine closure, not inclusive of annual costs of post-closure monitoring, is AUD 7.3 M, 
AUD 9.8 M, AUD 10.5 M, and AUD 1.9 M for the Options A, B, C, and D, respectively. However, the use of a high discount rate and the closure activities schedule selected for the base case scenario make these costs relatively less significant when compared to the costs to be incurred in the first years. As a result, despite Option $C$ having the highest rehabilitation costs, under the base case scenario it was found to be the cheapest alternative because its NPC was dominated by the costs to be incurred in the beginning of the LOM.

The better cost performance of Option A should be viewed with caution because it involves the management of a TSF designed for the storage of wet tailings, which may prove difficult and costly to close. Additional rehabilitation works to mitigate potential environmental impacts and unexpected regulatory financial costs in the future can be required for this option (McPhail 2006). Closure costs can be underestimated at the design phase of the project. The actual rehabilitation costs can be much higher at the time of closure. There are a variety of factors that may contribute to changes in the TSF closure cost estimates, such that calculated costs may have little resemblance to future real costs. For instance, the use of operational cost rates in mine closure accounting, as the efficiencies and productivity achievable during the operating LOM may not be translatable to closure. Reclamation and monitoring costs may also involve uncertainties reflected in the effect of changing regulations of mine closure and stakeholders' expectations of what can and should be achieved with rehabilitation. On the other hand, the disposal of filtered tailings (Option D) can allow progressive rehabilitation, spreading the closure costs throughout the LOM, and minimising rehabilitation efforts and the time required for post-closure monitoring. In this case, rehabilitation strategies can be trialled against completion criteria before closure. Progressive rehabilitation also has the potential to reduce annual payments into the WA MRF.

\subsubsection{Water scenario}

In the water scenario, a cost of AUD $5 / \mathrm{m}^{3}$ for the supply of make-up water was considered for estimating the NPC of each project option aiming at accounting for the benefits of reducing the requirement of make-up water as a result of more dewatering being applied to the tailings. The unit cost per tonne of tailings solids to be disposed of was estimated as AUD 1.90, AUD 2.87, AUD 1.41, and AUD 2.58 for the Options A, B, C, and $D$, respectively. The cost advantage of Option $C$ results from more dewatering being applied to the tailings at the plant (compared to Options $A$ and $B$ ), and the relatively high volume of precipitation runoff expected to be collected in the pond adjacent to the TSF and returned to the plant for use in the process.

It is important to note though, that the volume of precipitation runoff to be collected can vary a lot, particularly in the context of climate change. Hence, recovering water using the dewatering equipment at the plant may significantly reduce the cost of disposing tailings under the water scenario. Moreover, the cost of drilling boreholes for the supply of make-up water, and the regulatory financial costs of access to water were not accounted for in the cost estimates, but it is important to highlight that they may be expensive and could considerably affect the estimated costs of the designed projects.

\subsubsection{Land scenario}

In the land scenario, a cost of AUD $1 \mathrm{M} /$ ha (Cooling 2018) was considered in the financial analysis to account for the benefits of reducing footprint area required for tailings storage. The results show that the filtered tailings alternative (Option D) is the cheapest solution for the management of the tailings if land is expensive. The unit cost per tonne of tailings solids to be disposed of was estimated as AUD 4.14, AUD 5.52, AUD 12.33, and AUD 4.18 for the Options A, B, C, and D, respectively. A comparison of NPCs shows that the life cycle cost of Option $C$, which under the base case scenario resulted in the lowest NPC, is the highest and more than double the total costs of all the other options.

There are important considerations to be highlighted with regards to the land scenario. If there is no restriction to land access, such as in remote areas with suitable topographies, which allow the storage of the tailings over a large footprint, disposing thickened tailings using the CTD method may be economically attractive. It is because there is no need for raising a TSF perimeter embankment for tailings containment. However, in many cases land availability is limited due to technical or legal restrictions on land use, which 
may impose significant expenses and even impediments to the project. In other cases, land is expensive and competition for land use may increase, resulting in high investment costs required for the development of the operations. Furthermore, hidden costs of land can be internalised in the finances of the project in the form of onerous expenditures associated with permitting processes, obtaining a social license to operate, solving conflicts between stakeholders, etc. This is particularly true in the context of growing stakeholder expectations that the mining industry demonstrates high quality rehabilitation and lease relinquishment so that land can sustain an acceptable post-mining use.

\subsubsection{Carbon tax scenario}

In the carbon tax scenario, a cost of AUD 24.15/t of $\mathrm{CO}_{2}$ eq (World Resources Institute 2013) emitted was considered for calculating the NPC of each project option, resulting in the estimated unit cost per tonne of tailings solids to be disposed of as AUD 0.90, AUD 1.87, AUD 0.85, and AUD 2.34 for the Options A, B, C, and $D$, respectively. The objective of evaluating the project options under this scenario was to examine the effect of the reintroduction of a carbon pricing scheme in Australia on the total costs of tailings management. The results of a comprehensive LCA study conducted for this paper show that the direct (Scope 1) emission is $0.14 \mathrm{~kg} \mathrm{CO}{ }_{2} \mathrm{eq} / \mathrm{t}, 0.46 \mathrm{~kg} \mathrm{CO}{ }_{2} \mathrm{eq} / \mathrm{t}, 0.13 \mathrm{~kg} \mathrm{CO} \mathrm{CO}_{2} \mathrm{eq} / \mathrm{t}$, and $0.95 \mathrm{~kg} \mathrm{CO} \mathrm{C}_{2} \mathrm{eq} / \mathrm{t}$ for Options $\mathrm{A}, \mathrm{B}, \mathrm{C}$, and $\mathrm{D}$, respectively. It is important to note that these values should be scaled to other operations with caution because despite being directly proportional to the burn of fuel in earthmoving equipment, earthworks needed for each project option are not only proportional to the volume of tailings to be stored. Earthworks are also required for the construction of the TSF and associated infrastructure, TSF operation, and rehabilitation works, and these are not linearly proportional to the amount of tailings to be disposed of. Detailed life cycle inventories should be compiled for performing an LCA study to quantify GHG emissions for each specific case.

If the carbon price is accounted for, Option $\mathrm{C}$ remains the most economically feasible option. Compared to all the other options, Option $\mathrm{C}$ requires minimum earthworks throughout the LOM for the operation of the TSF. On the other hand, Option D is the least preferable solution as the ongoing tailings transport and placement by earthmoving equipment results in high GHG emissions. However, there is a possibility of using conveyor belts for transporting and mechanically stacking filtered tailings, which may significantly reduce environmental releases for Option D. On the contrary, the project designed for Option D also demands the highest energy input, and in the case that a carbon tax results in higher electricity costs due to overheads being passed on from energy companies to consumers, the costs of managing filtered tailings may rise even more.

\subsubsection{Potential total life cycle costs scenario}

In the potential total life cycle costs scenario, all the additional costs previously considered individually in the alternative scenarios were included for the estimation of the NPC of each project option. The results show that, for this specific case study, managing filtered tailings (Option D) is the most cost-effective solution for the disposal of the tailings, while being the most economically feasible option under three of six assessed scenarios, Option $\mathrm{C}$ is the least preferred option when the sum of potential hidden costs is accounted for in the evaluation of the project options.

Overall, under the potential total life cycle costs scenario (perhaps the most realistic case), the NPC of Option D only doubled compared to the $553 \%, 302 \%$, and $1,542 \%$ increase in the NPC of Options A, B, and C, respectively. It demonstrates that filtered tailings may have the highest resilience of the cost estimates to alternative input values and assumptions in the context of increasing challenges associated with mine closure, the use of natural resources and climate change. Furthermore, it is suggested that technology will continue to drive down the costs of producing filtered tailings, thus making it an increasingly competitive option compared with other conventional tailings disposal options.

There are other factors that could also affect costs and impact decision-making depending on the project location, although they were not considered here. Some of these factors include the distance of the TSF from 
the plant, limits on groundwater abstraction, potential groundwater impacts (which may require barrier and/or abstraction systems to minimise pollution), steep topography (which impacts on impoundment and deposition methods, and pumping capability), availability of spares and consumables for the mineral processing plant, community proximity to the TSF, and other risks, environmental and social issues that need to be dealt with on a site-by-site basis.

These factors can be addressed from a life cycle perspective, converted into monetary units, and integrated in the decision-making process to determine the economic feasibility of project options. A comprehensive methodology for the evaluation of tailings management options and an associated cost estimation tool being developed by the authors of this paper can easily accommodate these details, which will be discussed in future publications.

\section{Conclusion}

The life cycle costs of project options designed for the management of tailings in WA were estimated and compared under six different scenarios. In each case, key elements that may represent a project constraint for the chosen site-specific conditions, and which are likely to become more expensive in the context of increasing pressure on mining companies to adopt more sustainable practices, were tested. This was done to examine the extent to which uncertainties and potential sources of variability surrounding the project viability evaluation affect the total costs of tailings management, and the ranking between the selected options.

The main conclusion drawn from the discussion presented in this paper is that the cost estimates of project options designed for the disposal of tailings at low solids contents (slurry and thickened tailings) are more sensitive to changing input parameters associated with mine closure, the use of natural resources (water and land), and environmental regulations with regards to climate change. On the contrary, the project designed for managing filtered tailings was found to have the highest resilience of the cost estimates to the input values and assumptions tested. Although, under the base case scenario, managing thickened tailings (Option C) was found to be the most economically viable alternative, while managing filtered tailings (Option D) was the most expensive one, the reverse occurred under the scenario considering potential total life cycle costs. This is important information to be conveyed to decision-makers when a strategy for tailings management is to be selected from a variety of possible solutions. Particularly in the context of increasing scrutiny over the stewardship of tailings, it is very important to recognise that the attractiveness of reducing costs in the short-term must be carefully weighed against the possibility of increasing other potential costs throughout the LOM and beyond.

Adopting a robust approach to the selection of a tailings management strategy that encompasses design for closure and leading practices to lower the risk of catastrophic dam failures, optimise the use of resources, and mitigate environmental impacts is suggested to be a potential solution to meet increasingly stringent regulations for the development of new mining operations. In the future, the benefits of high-density tailings storage will become more prominent, particularly as external pressures force mining operators to look at alternative disposal methods, and technology may continue to drive down the costs of producing filtered tailings. The authors will continue researching how to identify and integrate other hidden and less tangible costs associated with the potential life cycle environmental impacts of disposing tailings and the risks of TSF failure in economic evaluations for the selection of the most sustainable and the most cost-effective solution for tailings management.

\section{Acknowledgement}

This paper presents part of the results of a project financially supported by The University of Western Australia and the Australian Centre for Geomechanics. The paper benefitted from fruitful discussions with researchers and industry professionals; these are gratefully acknowledged. 


\section{References}

Carneiro, A \& Fourie, AB 2017, 'Economic evaluation for the disposal of slurry versus thickened tailings in Western Australia - A case study', in GW Wilson, DC Sego \& NA Beier (eds), Proceedings of the Twenty-first International Conference on Tailings and Mine Waste, University of Alberta Geotechnical Centre, Edmonton, pp. 138-149.

Carneiro, A \& Fourie, AB 2018, 'A conceptual cost comparison of alternative tailings disposal strategies in Western Australia', in RJ Jewell \& AB Fourie (eds), Proceedings of the 21st International Seminar on Paste and Thickened Tailings, Australian Centre for Geomechanics, Perth, pp. 439-454.

Cooling, D 2018, Improving the Sustainability of Residue Management Practices, keynote speech presented at the 21st International Seminar on Paste and Thickened Tailings, 11 April 2019, Perth.

Cummings, J 2014, 'The mining industry and land rehabilitation in Australia-once were leaders?', Journal of Cleaner Production, vol. 84, pp. 39-40.

Department of Foreign Affairs and Trade 2016, Leading Practice Sustainable Development Program for the Mining Industry, viewed 1 October 2018, https://archive.industry.gov.au/resource/Programs/LPSD/Pages/default.aspx

Department of Mines, Industry Regulation and Safety 2013, Mining Rehabilitation Fund - Guidance, viewed 1 October 2018, http://www.dmp.wa.gov.au/Documents/Environment/ENV-MEB-382.pdf

Espinoza, RD \& Morris, JWF 2017, 'Towards sustainable mining (part II): accounting for mine reclamation and post reclamation care liabilities', Resources Policy, vol. 52, pp. 29-38.

Gluch, P \& Baumann, H 2004, 'The life cycle costing (LCC) approach: a conceptual discussion of its usefulness for environmental decision-making', Journal of Building and Environment, vol. 39, pp. 571-580.

International Council on Mining and Metals (ICMM) 2015, Sustainable Development Framework: ICMM Principles, viewed 1 October 2018, https://www.icmm.com/website/publications/pdfs/commitments/revised-2015_icmm-principles.pdf

International Council on Mining and Metals (ICMM) 2016, Position statement on preventing catastrophic failure of tailings storage facilities, viewed 1 October 2018, https://www.icmm.com/website/publications/pdfs/commitments/2016_icmmps_tailings-governance.pdf

ISO 2006a, ISO 14040:2006 Environmental Management - Life Cycle Assessment - Principles and Framework, https://www.iso.org/ obp/ui/\#iso:std:iso:14040:ed-2:v1:en

ISO 2006b, ISO 14044:2006 Environmental Management - Life Cycle Assessment - Requirements and Guidelines, https://www.iso.org /obp/ui/\#iso:std:iso:14044:ed-1:v1:en

Johnson, D, Moghaddam, R, Bin Ahmed, I \& Laroche, C 2013, 'Comparative evaluation of surface disposal of thickened versus slurry tailings', in RJ Jewell, AB Fourie, J Caldwell \& J Pimenta (eds), Proceedings of the 16th International Seminar on Paste and Thickened Tailings, Australian Centre for Geomechanics, Perth, pp. 289-302.

McPhail, G 2006, Implications of Different Tailings Disposal Options on Future Rehabilitation, viewed 1 October 2018, http://wwlengineering.com/wp-content/uploads/2016/10/MW-018-Tailings-Closure-G-McPhail-Final.pdf

Moreno, J, Kendall, S \& Ortiz, A 2018, 'Dewatering options for management of fine gold tailings in Western Australian Goldfields', in RJ Jewell \& AB Fourie (eds), Proceedings of the 21st International Seminar on Paste and Thickened Tailings, Australian Centre for Geomechanics, Perth, pp. 413-424.

National Greenhouse and Energy Reporting 2018, Greenhouse Gases and Energy, viewed 1 October 2018, http://www.cleanenergyregulator.gov.au/NGER/About-the-National-Greenhouse-and-Energy-Reporting-scheme/Greenhousegases-and-energy

PRé Consultants 2018, SimaPro Database Manual, Methods Library, viewed 1 October 2018, https://www.pre-sustainability.com/ download/manuals/DatabaseManualMethods.pdf

PRé Consultants 2019, SimaPro, version 8.5.2.0, computer software, PRé Consultants, Amersfoort, https://simapro.com

Robins, M 2004, Closure of Tailings Facilities: Current Practice Review and Guidelines for Success, viewed 1 October 2018, http://wiredspace.wits.ac.za/bitstream/10539/1851/1/Closurefinal.pdf

World Resources Institute 2013, GHG Mitigation in Australia: An Overview of the Current Policy Landscape, viewed 1 December 2018, http://www.climateinstitute.org.au/verve/_resources/TCIWRI_WorkingPaper_Australia.pdf 